npj|Microgravity

ERRATUM OPEN

\title{
Erratum: A hitchhiker's guide to an ISS experiment in under 9 months
}

Andrei James Nadir ${ }^{1}$

npj Microgravity (2017)3:19; doi:10.1038/s41526-017-0017-9

Erratum to: npj Microgravity (2017) 3:6; doi: 10.1038/s41526-0160003-7; Published 12 January 2017

In the original version of the article, Kevin Sato was incorrectly listed as an author instead of in the "Acknowledgements" section. The HTML and PDF version of the article has been corrected.

Open Access This article is licensed under a Creative Commons Attribution 4.0 International License, which permits use, sharing, adaptation, distribution and reproduction in any medium or format, as long as you give appropriate credit to the original author(s) and the source, provide a link to the Creative Commons license, and indicate if changes were made. The images or other third party material in this article are included in the article's Creative Commons license, unless indicated otherwise in a credit line to the material. If material is not included in the article's Creative Commons license and your intended use is not permitted by statutory regulation or exceeds the permitted use, you will need to obtain permission directly from the copyright holder. To view a copy of this license, visit http://creativecommons. org/licenses/by/4.0/

() The Author(s) 2017 